This work is licensed under a Creative Commons Attribution 4.0 International License.

Ovaj rad dostupan je za upotrebu pod međunarodnom licencom Creative Commons Attribution 4.0.

Krešimir Šimić

\title{
JOŠ JEDNOM O ALEGORIJI U MARULIĆEVU DIJALOGU O HERKULU
}

dr. sc. Krešimir Šimić, Sveučilište Josipa Jurja Strossmayera u Osijeku, Filozofski fakultet, ksimic@knjiga.ffos.hr, Osijek

izvorni znanstveni članak

UDK 821.163.42.09Marulić, M.

rukopis primljen: 27. rujna 2019; prihvaćen za tisak: 5. prosinca 2019.

U članku se prvo donose dosadašnji uvidi u Marulićev Dijalog o Herkulu, pri čemu se znatnija pozornost posvećuje radu Bratislava Lučina „Marulićev Hercules Moralisatus (o alegoriji u Dijalogu o Herkulu)" (1993). Zatim se prikazuje patrističko-medievalna tradicija tumačenja alegorije i tropologije. Konačno, iznosi se zaključak da Marulić Dijalogom moguće ne ocrtava samo kršćansko odbacivanje humanističkih tendencija ekstendiranja alegorije na mitologiju, nego i odbacivanje tropološkog tumačenja „pjesničkih bajki $i$ izmišljotina".

Ključne riječi: Marko Marulić; Dijalog o Herkulu; alegorija/alegoreza; patristika; skolstika; humanizam

I.

Nakon što je 1976. godine pronađen rukopisni kodeks - autograf nekih Marulićevih latinskih djela (Cod. Vallicellianus, sign. F 98) pozornost je isprva bila posvećena proznom spisu De Veteris Instrumenti viris illustribus commentarium, dotad poznatom samo po naslovu. Kasnije je pozornost privukla posveta-poslanica Tomi Nigru (Marcus Marulus Thome Nigro, Scardonensi episcopo, salutem plurimam dicit) - kojom mu Marulić posvećuje svoj Dialogus de Hercule a Christicolis superato. Dva su razloga zašto je posveta-poslanica privukla pozornost: prvo, ona se ne nalazi u tiskanom 
izdanju iz 1524. godine niti u onom iz 1549. godine (riječ je o prijevodu na talijanski jezik koji je sačinio Bernardino Chrisolpho); ${ }^{1}$ drugo, u njoj se spominje Erazmo Rotterdamski, ${ }^{2}$ što je za studij ranonovovjekovne hrvatske književne kulture važno jer upućuje na recepciju Erazma koja je gotovo neproučena (usp. Lučin 2004). ${ }^{3}$ Upravo je spominjanje Erazma

1 B. Glavičić je iz podnaslova Chrisolphova prijevoda (di latino in volgare nuovamente tradotto) zaključio da je postojao još jedan prijevod na talijanski prije 1549. godine, koji nam je zasad nepoznat. Također spominje mogućnost izdanja na latinskom starijega od onoga iz 1524. godine (Glavičić 1992: 15). L. Košuta je pak ustvrdio da nuovamente tradotto ne upućuje na drugo izdanje, pa je stoga izdanje iz 1549. prvo na talijanskom jeziku (Tomasović 1996: 72).

2 „Primio sam knjige Erazma Roterdamskog što si mi ih poslao: odlikuju se pobožnošću, učenošću i, ne manje, rječitošću. Veoma uživam čitajući ih. I doista, od vremena svetog Jeronima pa sve do naših dana u naših bogoslova nije bilo one ljepote profinjena izražavanja. Hvalili smo u mnogih oštroumnost rasuđivanja i zaključivanja, ali tko je iole uživao čitajući antičke pisce, nije mogao čitati njihove spise a da ne osjeti dosadu. Sada je, međutim, zahvaljujući Erazmu, sama zgrada svete Crkve, koja je zbog nebrige tih jednostavnih mislilaca bila gotovo gola, ponovo zablistala od drevnih ukrasa te se sja oličena bojama krasnorječja. Priliči, dakle, itekako da se radujemo i kličemo što su se stvari, milostivošću Božjom, počele već vraćati u prvotno stanje. Opet će sveta književnost i nauka imati svoje Jeronime i Ambrozije, ako se samo nađe onih koji će se htjeti takmičiti s Erazmom. Pa budući da sam nedavno od Tebe primio veoma lijepe njegove spise - da se ne bih pokazao krajnje nezahvalnim, namijenio sam Ti svoga Herkula, nekoć Jupitrova sina, koji se nedavno ponovo rodio, ovoga puta u nas" (Usp. Marulić 1992: 19-20; nadalje za navedeno djelo koristim kraticu LMD I).

[„Erasmi Roterodami libellos, quos misisti, accepi, pietatis eruditionisque plenos nec eloquentię minus. Magna me afficiunt uoluptate legentem. Etenim post diui Hieronymi tempora ad nostram usque ętatem abfuit a theologis nostris excultę orationis lepos. Laudabamus multorum in syllogismis enthimematisque argutias, quorum tamen scripta nemo lectione antiquiorum uel parum delectatus absque tedio legere poterat. At nunc Erasmo autore ipsa ecclesię sanctę structura, quę per istorum simpliciter philosophantium negligentiam pene nuda erat, pristinis reclarescit pigmentis rhetoricisque coloribus linita illustratur. Gaudere igitur et exultare maxime nos decet, quod iam Deo propicio res restitui in integrum coepit. Rursum sacrarum litterarum schola suos habitura est Hieronymos, suos Ambrosios, si modo, qui Erasmum emulari uoluerint, reperientur. Cuius uenustas admodum conscriptiones cum abs Te nuper acceperim, ne omnino ingratus uidear, Herculem, Ioue quondam natum, sed iterum proxima foetura apud nos ęditum, ad Te destinauimus."] (usp. LMD I: 21-22).

3 B. Lučin u svom radu (Lučin 2004) donosi pregled Erazmovih veza, izravnih i neizravnih, s humanističkim piscima, teolozima i diplomatima koji su rođenjem ili podrijetlom iz Hrvatske (Jakov Baničević, Stjepan Brodarić, Franjo Trankvil Andreis, Antun Vrančić, Ivan Česmički, Juraj Dragišić, Franjo Niger, Matej Fortunat, Petar Pavao Vergerije mlađi) te ukazuje na njegovu recepciju u hrvatskoj šesnaestostoljetnoj književnoj kulturi 
izazvalo znatniji interes marulologije. ${ }^{4}$ Sâmom Dijalogu, s obzirom na njegovu važnost za razumijevanje Marulićeva opusa, posvećeno je relativno malo pozornosti: lociran je u kontekst renesansnog proturječja (mitologija i kršćanstvo) (Tomasović 1986 i von Erdmann 2010), doveden je u mogući odnos spram Bunićeva epa De raptu Cerberi (Fališevac 1991), analizirani su estetički nazori koji se kriju u njemu (Posavec 1989), tipografske i tekstološke posebnosti (Jovanović 2004), isticano je da je njegova središnja os gnoseološka vrijednost pjesništva (Novaković 2005), odnosno „evanđeoska istina" (Manavski 2017). Za namjeru ovoga članka važniji su i smjerodavniji uvidi Bratislava Lučina koje je iznio u radu Marulićev Hercules Moralisatus (o alegoriji u Dijalogu o Herkulu). Stoga ću nadalje nešto veću pozornost posvetiti upravo spomenutom radu.

II.

Lučin rad o alegoriji u Dijalogu (Marulićev Hercules Moralisatus [o alegoriji u Dijalogu o Herkulu]) započinje konstatacijom da je upravo alegorija jedna od ključnih sastavnica, štoviše „strukturna i idejna osnovica” jedinog Marulićeva proznog djela napisanog u dijaloškoj formi i jedinog djela u njegovom obimnom opusu koje tematizira lik antičke mitologije (Lučin 1993: 16-17). Da bi objasnio svoju početnu konstataciju, Lučin donosi kratku analizu tekstovne kompozicije a potom tekst locira u vertikalni i horizontalni okoliš.

(Marko Marulić, Vinko Pribojević, Damjan Beneša, Nikola Petrović, Matija Vlačić Ilirik, Antun Vramec). Marulićeve riječi iz posvete-poslanice T. Nigru u kojima se spominje Erazmo B. Lučin navodi in extenso (Lučin 2004: 17).

4 Glavičić 1981 (isti članak objavljena je pod naslovom Marko Marulić i Erazmo Roterdamski u LMD I: 9-16), Béné 2001, Kraljić 2017. Na neke dodirne točke Erazmova djela Enchiridiona militis Christiani (koje je zasigurno bilo među djelima koja je Marulić primio od T. Nigera) ukazao je F. Šanjek (Šanjek 1989). O sličnosti Erazmovih stavova iznesenih u Enchiridionu i Marulićevih nazora usp. Lučin 1993: 22-23. B. Lučin također napominje da se posveta-poslanica (točnije njezin središnji dio, u kojemu Marulić izražava oduševljenost Erazmom) „može čitati kao sažeti manifest kršćanske koncepcije književnost koja se u recentnoj humanističkoj misli naziva theologia rhetorica” (Lučin 2000: 65). (Izraz „theologia rhetorica" B. Lučin je preuzeo od C. Trinkausa. Usp. Trinkaus 1970: 126-128, 141-142 i 615-650). Polazeći od pomne analize posvete-poslanice u kojoj se spominje Erazmo, B. Lučin nešto opširnije obrazlaže „teološku retoriku” u radu Marko Marulić $i$ theologia rhetorica (2001). O posveti-poslanici, u kontekstu svih Marulićevih posveta-poslanica, pisala je Zlata Bojović (Bojović 1989). 
Kompozicija Dijaloga je „čvrsta i pregledna” (topička uokvirenost i simetričnost: sugovornici, Pjesnik i Bogoslov, susreću se u shematično naznačenom krajoliku; razgovor traje od podnevne žege do pred zalazak sunca; razgovorom, izuzev uvodnih, središnjih i završnih kraćih replika, dominiraju dva dulja monologa - u prvom Pjesnik pripovijeda o Herkulovim djelima, a u drugom Bogoslov istim redom izlaže njihovo kršćansko alegorijsko tumačenje; oba se monološka izlaganja prekidaju kraćim dijaloškim umecima, koje Lučin naziva „ideološkim interludijima”, na istom mjestu - između Herkulovog erga (dvanaest zadanih mu pothvata) i parerga (ostalih, „usput” učinjenih djela) (Ibid.: 17). ${ }^{5}$

Opis tradicijskog okoliša Lučin započinje rečenicom iz Dijaloga koju drži ključnom:

„Pa ipak, pjesnici štošta izmišljaju pod čime hoće da se krije alegorija bilo prirode bilo značaja, bilo da je riječ, štaviše, o zamračenu značenju u vezi s nekim stvarnim događajem." (LMD I: 74)

„Quanuis a poetis plurima fingantur, sub quibus alegoriam latere uolunt siue naturę siue morum siue etiam adumbratę circa rem gestam significationis." (LMD I: 114)

5 D. Fališevac napominje da je „Marulićev moralistički dijalog, izrazito obilježen programatskim književnokritičkim i književnopolemičkim stavovima - i tim svojim osobinama sličan dijalozima Poggia Bracciolinija (i njegovi su dijalozi koncipirani prvenstveno kao moralne debate iz kojih se izvode određeni literarni programi, i njegovi dijalozi imaju lik teologa koji svojom argumentacijom nadglasava ostale sudionike)" (Fališevac 1991: 76). Iako je možda riječ o formalnoj sličnosti, upitno je moguće bitnije podudaranje Bracciolinija i Marulića. Naime, Bracciolini smatra da se humanističko oživljavanje klasične i kršćanske književne tradicije treba ostvariti metodom imitatio, a ne metodom eruditio (filološko „kritičko” istraživanje klasične i kršćanske književne kulture, pri čemu filološka analiza treba postati osnovni analitički alat za novo epistemološko utemeljenje svih znanosti, pa tako i teologije - što znači da se smisao „teološke retorike” ne iscrpljuje u pukom izlaganju teoloških tema na „retorički način”, već da retorika postaje znanost jezika, svojevrsna science-of-method, Wissenshaftslehre). Upravo je Erazmo, kojega je oduševljeno prihvatio Marulić, oduševljeno prihvatio metodu eruditio, čiji je najpoznatiji zastupnik Lorenzo Valla (Camporeale 2001). Da se vratim formalnoj strani: Možda bismo, doduše vrlo oprezno, Marulićev Dijalog mogli dovesti u svezu s tzv. „ciceronovskim dijalozima", čije su dvije osnovne odrednice da se razgovor (koji je svojevrsno filozofijsko istraživanje) vodi u dokoličnom povlačenju i da su osobe koje razgovaraju učene (Marsh 1980: 8). 
Riječ je o „racionalističkom” tumačenju mitova (poglavito bogova) što su ga razradili stoičari, široko primjenjivali novoplatoničari, a koje se još u antici konstituiralo u tri glavna sustava. Sva tri uspostavio je Ciceron u De natura deorum. Lučin ih svodi na sljedeće značajke: 1) mitovi manje ili više iskrivljeno pripovijedaju zbiljske događaje iz daleke prošlosti kojima su sudionici bili ljudi koje su zbog njihovih slavnih djela kasnije smatrali bogovima; 2) mitovi su izrazi čovjekovih doživljaja prirodnih pojava i sila, što znači da su bogovi njihovi simboli i 3) mitovi su moralne i filozofske ideje zaodjenute u kakvu priču, pa su onda bogovi alegorije tih ideja. Prvi se obično naziva povijesnim ili euhemerističkim, drugi naturalističkim i treći moralističkim. Iz toga onda proizlazi da se u Dijalogu "alegorija prirode” odnosi na naturalističko tumačenje, "alegorija značaja” na moralističko i „zamračeno značenje u vezi s nekim stvarnim događajem” na povijesno tumačenje (Lučin 1993: 17-18). Sâmom Maruliću, napominje Lučin, najbliži je treći sustav (moralistički) „kako zbog njegova općeg duhovnog profila tako i zbog pogleda na ulogu i svrhu književnosti, ali zacijelo i zbog toga što se takvo tumačenje dodiruje $s$ jednim od četiriju načina svetopisamske alegoreze: s iznalaženjem tropološkog smisla, koji se još naziva i moralnim (ćudorednim)" (Ibid.: 19).

Nadalje Lučin ukratko ocrtava odnos kršćanstva prema mitologiji sub specie tropologiae, a onda i prema sâmom Herkulu unutar te tradicije. Krajnje sažeto: unatoč patrističkom odbacivanju moralne alegoreze mitova (Origen, Laktancije, Arnobije, Augustin) izvođenje kršćanskih moralističkih poruka iz mitologije postaje svojevrsna philosophia moralis. Štoviše, u srednjovjekovnoj književnoj kulturi prefiguracije kršćanske istine nazirale su se ne samo u osobama i epizodama Staroga zavjeta nego i u osobama i epizodama mitova (Bernard iz Chartresa, Ivan iz Salisburyja, Ivan iz Garlandea, Giovanni del Virgilo, Robert Holkot), što svoj apogej doživljava u ranom novom vijeku (Giovanni Boccaccio, Coluccio Salutati, Angelo Poliziano, Cristoforo Landino). Tada dolazi i do „konkordiranja” Platona i Mojsija, Sokrata i Isusa. Vrijeme je to kada počinje prevladavati mišljenje da se pod različitim oblicima krije zajednička istina. U takvom ozračju (nastojanju da se kršćanska objava harmonizira s antičkom baštinom) Herkul postaje figura Christi. Osnovne linije razvoja kristijanizacije Herkula su sljedeće: već na kraju antike pojavljuje se Sinezijeva himna u kojoj Herkulova katabaza asocira na Kristovu, zatim se na kraju srednjeg vijeka i početkom ranog novog vijeka pojavljuje anonimna Canzone u kojoj se Krist sustavno izjednačuje s Herkulom, konačno dolazi traktat Coluccia Saltutatia 
De laboribus Herculis te, spomenimo i to, Bunićev ep De raptu Cerberi (Ibid.: 19-22 i Novaković 1991: 97-98). ${ }^{6}$

Lučin smatra da je pri nastanku Dijaloga stanovitu ulogu, zapravo ulogu svojevrsna brevis summa naznačene dugotrajne i razvedene tradicije imao Boccaccio svojom mitološkom enciklopedijom Genealogie deorum gentilium libri i raspravicom Trattatello in laude di Dante (oba djela navedena su u popisu zatečenih knjiga Marulićeve ostavštine: Genealogia deorum quadernus i Johannes Bocatius super Dantem). ${ }^{7}$ Osim toga, Lučin je uvidio i još jednu tradicijsku crtu Marulićeva Dijaloga. Uz možebitno domišljato inoviranje tropološkog tumačenja Herkulovih djela, što zapravo nije ništa novo (takva domišljatost bila je dopuštena čak i pri biblijskoj egzegezi) (Glavičić 1989: 154-155), ${ }^{8}$ Dijalog nije, tvrdi Lučin, „naprosto Hercules

6 B. Lučin se oslonio na knjigu Jeana Sezneca La survivance des dieux antiques (Paris, 1980), a D. Novaković donio je zapravo sažet prikaz knjige Marcela Simona Hercule et le christianisme (Strasbourg, 1955). Na Simonovu knjigu osvrnuo se i C. Béné, ali polemički: upućujući na „prazninu” i svojevrsnu nedosljednost. Naime, M. Simon piše o Herkulovu silasku u Pakao i hvatanju psa Kerbera u Dantea, a zatim o Ronsardovu Hercule Crestien, što je „skok” od dva stoljeća (1321-1555). Osim toga, M. Simon piše o polemičkoj književnosti reformacijskih teologa koji optužuju Ronsardovo „poganstvo” (usporedba Herkula i Krista), iako je, napominje C. Béné, poznato da su se usporedbi Herkula i Krista oštro opirali već patristički autori (Origen, Contra Celsum, VII, 54; Augustin, De civitate Dei, XVIII, 12 i Laktancije, De divinis institutionibus, I, 9 i 18), pa je vjerojatno da je otpor takvoj usporedbi postojao i znatno prije pojave reformacijskih pisaca (Béné 1994). Budući da se oslonila na knjigu Epische Stoffe des Mittealalters (1984), D. Fališevac je donijela nešto drugačije ocrtanu herkulovsku tradiciju od one koju su prikazali B. Lučin i D. Novaković: Diktisove i Daresove kompilacije grčkih epskih ciklusa o Argonautima, tebanskom ratu i drugih priča iz antičke mitologije, Ovidije, Boetije, Carmina Burana, Prodiko, Enriques de Villena (Fališevac 1991: 68).

7 Doduše, Boccacciov prikaz mita o Herkulu (Gen. XIII, 1), napominje B. Lučin, nema sličnosti s Marulićevim Dijalogom, ali rečenica iz Genealogie: „... [poete] sub fictionibus suis naturalia contegunt atque moralia et virorum illustrrium gesta." (XV, 8) vrlo je bliska Marulićevoj: „Quanuis a poetis plurima fingantur, sub quibus alegoriam latere uolunt siue naturę siue morum siue etiam adumbratę circa rem gestam significationis." (LMD I: 114) Nadalje, u dvama poglavljima Trattatella (XXI: Digresija o podrijetlu pjesništva i XXII: Obrana pjesništva) Boccaccio je, kadšto istim riječima kao u posljedna dva poglavlja Genealogie (XIV i XV), izložio naturalističko i povijesno tumačenje postanka bogova a potom i kako pjesništvo, po uzoru na Sveto pismo, čitatelju - ako je valjano, tropološki, protumačeno - pruža vrijednu kršćansku pouku (kao primjer spominje se i Herkul). Na istom mjestu govori se i o odnosu poezije i teologije prema istini (usp. i Gen XIV, 13: „Poetas non esse mendaces.”) (Lučin 1993: 24-25).

8 Jeronim je ograničenost povijesnog i slobodu tropološkog tumačenja sažeo izrazom: „historia, stricta; tropologia, libera” In Abd. 1, 6 (PL, 25: 281-282) Navedeno prema: de Lubac 
moralistaus, nego još i Hercules superatus" (Lučin 1993: 26). To znači da se Herkulovi pothvati ne „dekodiraju” samo (tropološkom) alegorezom, već se uvodi i sustav nadmašivanja (prvo se uspostavi što iscrpniji niz paralelizama, uvjetnih jednadžbi između elemenata mitske priče i postupaka poželjnih za kršćanski život, konačno se ističe da preneseno značenje nadmašuje doslovno). Takvu strukturu Marulić je vjerojatno izveo, napominje Lučin, iz postupka kojim je kršćanski apologet Laktancije pobijao tobožnje božanstvo antičkog heroja (Ibid.: 27). ${ }^{9}$

Iz ocrtanog tradicijskog okoliša, vertikalnog i horizontalnog, i kontekstualiziranja Dijaloga unutar njega Lučin dolazi do zaključka: „Marulić ne zabacuje svaku uporabu mitologije u kršćanske svrhe, no zazoran mu je tipološki odnos među tim za njega nepomirljivo različitim svjetovima. On bira srednji put: tropološku alegorezu, s primjesom dodatne suzdržanosti što se očituje u naglašenu insistiranju na shemi nadmašivanja" (Ibid.: 28).

U radu Gli studia humanitatis del Marulić Lučin je iz jedne šire perspektive, pogled na Marulićev opus, u nekoj mjeri sažeto ponovio tvrdnje iznesene u radu iz 1993. godine. Istaknuo je da je Marulić Dijalogom „pokazao da nije stručnjak samo za alegorijsku egzegezu (esegesi allegorica) Biblije već i za kršćansku alegorezu mitološke građe, za 'moralizaciju' mitova ('moralizzazione' dei miti)”, za moralističku, „tropološku alegorezu” (allegoresi tropologica) mitova (Lučin 2000: 71). Pod uvjetom da se sačini

1998: 280. (Nadalje, ukoliko nije drugačije naznačeno, citate patrističkih i medievalnih autora navodim prema: de Lubac 1998 i de Lubac 2000.) Ipak, tropološka biblijska egzegeza nije bila u potpunosti oslobođena pravila (Jeronim, In Is.: PL, 24: 259 C; In Amos: PL, 25, 1018 C; In Hab.: PL, 25, 1281-1282). Beda Časni ističe da je tropološka egzegeza povezana s moralnim razumijevanjem: „tropologice, id est, juxta moralis intelligentiae regulas.” In Sam (PL, 91: 151 D). Inače, patristički i medievalni autori isticali su da "duhovno” razumijevanje ima svoju objektivnu strukturu, odnosno vlastite distinktivne značajke - jer u stvarima postoji načelo koji proizlazi iz božanskog zakona. Stoga i četiri biblijska smisla korespondiraju s četiri pravila tumačenja (de Lubac 1998: 16-17).

9 Laktancije je u prvoj knjizi (De falsa religione) svojega djela Divinae institutiones, u poglavlju De Hercule et eius vita et morte prvo ukazao na to da su pobjeda nad lavom i veprom, obaranje ptica strijelama, čišćenje staje i dr. djela doduše snažna muža, ali ipak čovjeka, a onda je konstatirao da se ne valja snažnijim smatrati onoga tko nadvladava lava od onoga tko nadvladava u samome sebi zatvorenu zvijer - gnjevljivost itd. Konačno, konstatira da samo onoga treba držati snažnim mužem tko je umjeren, razborit i pravedan. U istoj knjizi Laktancije raspravlja i o tome koliko treba vjerovati pjesnicima, a u trećoj knjizi (De falsa sapientia philosophorum) obrušio se na antičke filozofe (Lučin 1992: 27). Da se upravo u Laktancija nalazi „bît Marulićeve argumentacije” (kršćanska su djela izvrsnija od Herkulovih), tvrdi i C. Béné (Béné 1994: 154). 
„tropološka alegoreza”, smatralo se, mitovi mogu biti edukativno korisni (Ibid.). Stoga, ističe Lučin, alegorizacijom mita i legitimizacijom pjesništva Marulić se svrstao među predstavnike „teološke poetike” (theologica poetica), koja se u talijanskoj književnoj kulturi proteže od Petrarke do Tassa (Ibid.: 72).

Smatram da je Lučinova tvrdnja da je Maruliću „zazoran” tipološki model tumačenja mitologije - što implicira bitnu razliku između klasične i kršćanske strukture alegorije, koja se temelji na uvažavanju povijesnog smisla nezamislivog stoičko-neoplatoničkoj tradiciji - iznimno važna jer baca novo svjetlo na razumijevanje Marulićevih epova. Ilustrativni primjeri su radovi Ružice Pšihistal, koja je u marulološkim studijama donijela dosad najiscrpniji i najpregledniji prikaz kršćanske alegorije (allegoria in facto) (Pšihistal 2005: 43-83). ${ }^{10}$ Polazeći upravo od naznačenog (bitna razliku između antičkog i patrističko-medievalnog tumačenja alegorije/alegoreze), ona je, za razliku od dotadašnjih interpretacija u ključu „političkih tipologija”, ustvrdila da Juditu ne bismo trebali čitati kao alegoriju, već kao egzempl. Marulić se u Juditi, ističe Pšihistal, mogao zadržati na doslovno-historijskoj razini jer se u njoj nalazi jasna i nedvosmislena kršćanska teologija povijesti (starozavjetno teocentrično tumačenje povijesnih zbivanja eksplicitno se tumači riječima Akiora, stranca-poganina) (Pšihistal 2002). Što se tiče Davidijade, Pšihistal je ustvrdila da je pitanje je li Marulić otpočetka ep zamislio kao alegoriju ili je alegorijsko tumačenje proveo tek naknadno zapravo sekundarno jer je tipologija determinirala da prvi, odnosno doslovni smisao ostane netaknutim. Tipološki je pristup, zaključuje Pšihistal, omogućio i da ep može (i mora) funkcionirati bez alegorijskog tumačenja iz čega onda proizlazi da ep i Tropologica Davidiadis expositio imaju neovisan status (Pšihistal 2004).

Lučinovo mišljenje modificirala je Elizabeth von Erdmann. Ona je Marulićevu poetiku povezala s alegorijskom egzegetskom tradicijom, a ovu pak s (neo)platoničkom alegorezom Homera i patrističkim autorima (von Erdmann-Pandžić 2000: 326 i von Erdmann 2010:126), pa stoga Lučinovu tezu da su Pjesnik i Bogoslov zapravo predstavnici dviju glavnih struja unutar humanizma (a ne zastupnici posve suprotstavljenih svjetonazora) „ublažava” mišljenjem (točnije dojmom - „Meinem Eindruck”) da je razlika između njih (Pjesnika i Bogoslova) bitno manja, odnosno „jedva prepoznatljiva” (von Erdmann-Pandžić 2000: 323, bilješka 35). Štoviše, von Erdmann tvrdi da

10 Usp. Grmača 2015: 31-62. 
postoji „identitet između Marulićevog mišljenja i neoplatoničko-kršćanskog svjetonazora" (Ibid.: 326). Usuprot takvom modificiranju mislim da je Lučinovo mišljenje moguće modificirati u suprotnom smjeru: razlika između Pjesnika i Bogoslova je znatno veća - jer Marulić, mislim, ne odbacuje samo tipološko tumačenje mitologije nego i tropološko. Da bih pokazao što mislim, prvo ću naznačiti bitnu razliku između klasičnog i patrističko-medievalnog tumačenja alegorije/alegoreze te na shvaćanje tropološkog tumačenja koje iz takve razlike proizlazi. Pritom ću se uglavnom osloniti na iscrpna istraživanja Henrija de Lubaca (de Lubac 1998 i de Lubac 2000), koji unatoč tomu što patrističko-medievalna egzegetska tradicija nije monolitna osvjetljava dubok jaz između patrističkih i srednjovjekovnih autora i stoičko-platoničkih, što onda omogućava jasniji uvid u srž skolastičko-humanističkih prijepora, odnosno, smatram, u sâm Dijalog.

III.

Klasična retorička definicija alegorije (koja je u Kvintilijana zadobila formulaičan iskaz: aliud verbis, aliud sensu [Inst. or. VIII, 6, 44]) i njezini hermeneutički modeli (primjerice, Heraklitovo alegorijsko tumačenja Homera i Filonova „kozmološka alegoreza”) ${ }^{11}$ nisu osnovica na kojoj se razvija patrističko-medievalna egzegetska tradicija - krajnje je sažet zaključak koji je de Lubac donio nakon vrlo opsežnih istraživanja. Riječ alegorija u kršćansku egzegetsku tradiciju dolazi iz Pavlove Poslanice Galaćanima, u kojoj Pavao aludira na priču o Hagari i Sari iz Knjige postanka kao alegoriju: „hattina estin allêgoroumena" (4, 24). U Pavla je riječ alegorija hapax legomenon - koja je značila sasvim originalnu misao, nepoznatu i Grcima i Židovima. Tertulijan i Origen izraz alegorija, pa i model alegoreze (tipološki), preuzimaju upravo od Pavla, a ne od stoika ili platoničara (de Lubac 2000: 4-7). Isto čine i drugi patristički autori, primjerice Hilarije, Ambrozije, Augustin. Nakon što je naveo iscrpan katalog patrističkih i medievalnih autora, de Lubac je zaključio: Antiohija i Aleksandrija, grčka i latinska tradicija, unatoč različitim izrazima (allegoria, figura, typus, mysterium, sacramentum), složili su se u razumijevanju Apostola i slijedili ga (Ibid.: 9). Dakle, genus kršćanske alegorije/alegoreze nije stoičko-platonički!

11 E. R. Curtius (Europäische Literatur und Lateinisches Mittelalter, 1948), J. Pépin (Mythe et allégorie: les origines grecques et les contestations judéo-chrétiennes, 1958) i J. Seznec (La survivance des dieux antiques, 1980) ilustrativni su primjeri povezivanja homerske i kršćanske alegoreze, pri čemu je „helenizirani Židov” Filon Aleksandrijski ključna poveznica. 
Novum kršćanske alegorije u odnosu na stoičko-platoničku tradiciju u literaturi se često sažima na sljedeći način: usuprot klasično-antičkog tipa alegorije poznatog pod nazivom allegoria in verbis, pojavio se kršćanski tip alegorije poznat pod nazivom allegoria in factis. ${ }^{12}$ „Alegorija u riječima” sastoji se od niza metafora, a njezino tumačenje zasniva se na supstituiranju „doslovnog smisla” („kore”) prenesenim (,jezgra”). Faktualna alegorija zasniva se na „izvanjezičnoj zbilji” koja se ne smije supstituirati alegorijskim smislom. Stoga kod allegorie in factis nije riječ samo o novom retoričkom značenju ili hermeneutičkom modelu već i o jednom novom shvaćanju povijesti, pa čak i o novoj somatologiji. ${ }^{13}$ Za patrističke i medievalne autore historia (što je izraz koji su sinonimno koristili za littera, prvi i temeljni smisao biblijskih tekstova) nema veze s pukim narativnim strukturiranjem činjenične građe ili rankeovskim puštanjem da činjenična građa sâma govori („wie es eigentlich gewesen”), već je riječ o „figuralnom viđenju povijesti”

12 Kanonsku definiciju faktualne alegorije donio je Augustin, zasnivajući je upravo na Gal 4, 24: „Sed ubi allegoriam nominauit apostolus non in verbis eam reperit sed in facto cum ex duobus filiis Abrahae, uno de ancilla, altero de libera, quod non dictum sed etiam factum fuit duo testamenta intellegenda monstrauit." De Trin. XV, IX, 15. E. Auerbach u svojoj glasovitoj studiji Figura faktualnu alegoriju naziva "stvarno proroštvo" (phenomenal prophecy), što, mislim, dobro pogađa smisao specifičnosti patrističko-medievalne egzegeze. Zapravo, u prikazu specifičnosti patrističko-medievalnog figuralnog tumačenja u odnosu na klasičnu alegorijsku egzegezu E. Aurebach se ne razlikuje znatno od H. de Lubaca, međutim kada ističe figuralnu strukturu Danteove Divina Commedia, udaljuje je se od kršćanskog shvaćanja „svete povijesti” (Helisgeschichte) jer svoj pristup zasniva na Hegelovoj filozofiji povijesti (Auerbach 1084: 71).

13 Medievalni autori su littera dovodili ne samo u svezu s historia već i s corpus: „Littera est sicut corpus hominis: quae littera est ipsa historia.” PL, XCVI, 985 A. „Tijelo Kristovo podrazumijeva također i Pismo”, ističe pisac De unitate Ecclesiae conservanda („Corpus Christi intelligitur etiam Scriptura Dei." PL, CLXXVII, 519 A. Posebnost kršćanske somatologija najjasnije se očituje u inkarnacijskoj teologiji, teologiji uskrsnuća i, dakako, euharistijskoj teologiji (transuspstancijacija). Medievalni autori razvili su i nove epistemološke modele. A. Nemetz je srednjovjekovno tumačenje literalnog klasificirao u tri epistemološka modela: kulturalni (da bi se odredilo značenje, odnosno smisao, potrebno je oslanjanje na historijske okolnosti koje okružuju originalnog pisca), ideacijski (da bi se odredio smisao, potrebno je oslanjanje na verbalni kontekst danog teksta, pa se stoga izdvajaju paralelni tekstovi) i bihevioralan (da bi se odredio smisao, potrebna je dispozicija povezana, odnosno prethodeća otkrivanju smisla, značenja). Ta tri tipa dovode i do različitih naglasaka u teorijama signifikacije. Pretpostavke kulturalnog tipa rezultiraju u gramatikalnom naglašavanju značenja riječi koje je historijski determinirano, ideacijskog tipa u dijalektičkoj ili logičkoj analizi značenja, bihevioralnog tipa u retoričkoj teoriji signifikacije. Predstavnici tâ tri tipa su Isidor, Abelard i Bernard (Nemetz 1959: 76-89). 
(Auerbach 1984: 60), odnosno konceptu, kako su to nazivali medievalni teolozi, „oikonomia spasenja” ili, prema devetnaestostoljetnim teolozima, „sveta povijest" (Heilsgeschichte). ${ }^{14}$ Duhovni smislovi (alegorijski, tropološki i anagogijski) - isticali su kršćanski autori - neodvojivi su od historijskog. ${ }^{15}$ Cijela građevina significatio, tvrdio je Augustin, odlepršala bi u zrak bez fundamentum rei gestae. Raoulo iz Saint Germaina pisao je o Crkvi kao hramu Božjem čiji je prag historijski smisao Pisma, pa se stoga u hram može ući samo „vjerom u povijest” (per fidem historiae) (In. Lev. X, c. i [PL, 142 D]). Historiae intelligentia, intelectus litterae, intellectus signatus in historia samo su neki od izraza kojima su patristički i medievalni autori isticali neophodnost ratio historiae - ,jer povijest ima svoje vlastitio značenje” (Origen, Sel. in Ez. c. xxviii [PG, XIII, 821-2 C]). „Duh” ne egzistira bez historijskog, niti je historijsko odvojeno od „Duha”. Oba smisla - historijski (literalni) i duhovni - nalaze se jedan u drugome, kao „kotač u kotaču” (usp. Raban Mauro, In Ez. XVII [PL, CX, 978 C]). Kada Pavao i kršćanski autori razlikuju „slovo” i „duh”, biblijsku povijest i otajstvo, sjenu i istinu, oni nisu vođeni, čak ni neizravno, platoničkim razlikovanjem mnijenja i pravog znanja, egzegeze kata doxan i kata alêtheian (de Lubac 2000: 102). Usuprot - klasična grčka alegorizirajuća tradicija svojevrsnom je „intelektualnom alkemijom”, tvrdi de Lubac, nastojala harmonizirati mit i razum te tako sve zapravo preoblikovati u ideju (Ibid.: 105). ${ }^{16}$

No, kršćanska alegorija nije samo allegoria in factis - ona je allegoria facti et dicti: u Bibliji Bog govori riječima o djelima/događajima kojima je progovorio. Stoga su kršćanski autori isticali da i u Bibliji postoji „alegorija u riječima”, ali je nisu brkali s faktualnom alegorijom. ${ }^{17}$ Jasnoću $u$

14 Suprotstavljajući se liberalnom „historicizmu” i hegelijanskom idealističkom monizmu, koncept „povijesti spasenja” (Heilsgeschichte) koji je vrlo blizak „oikonomiji spasenja” razvili su devetnaestostoljetni protestantski teolozi (primjerice, J. T. Beck i J. C. K. von Hofmann).

15 Nakon što je analizirao brojne grčke i kršćanske autore, H. de Lubac je zaključio da kršćanski egzegeti nisu tretirali povijest kao što su antički tretirali mitove. Kršćanski su autori, naime, snažno isticali „stvarnost”. H. de. Lubac je potom poentirao: „Kakav ponor između Pseudo-Heraklita, Plotina, Salustija, njihovih srodnika i kršćanskih egezegeta!" (de Lubac 2000: 15). Na drugom mjestu H. de Lubac je ustvrdio da između antičkih grčkih i kršćanskih autora postoji „razlika u sâmoj strukturi simbolizma” (Ibid.: 103).

16 Liberalni protestantski teolog A. von Harnack je smatrao da je u Origenovoj egzegezi riječ o „biblijskoj alkemiji”, što su $\mathrm{H}$. de Lubac i J. Daniélou nastojali opovrgnuti ističući da Origen, iako nije shvatio da i metaforički smisao može biti literalni, zapravo nije zanemario sensus litteralis (Brown 1968: 611).

17 Već je Origen je u Peri archôn (IV, c. iii, n. 5) ustvrdio da nema sve u Bibliji doslovno značenje (sensus litteralis). Augustin je razlikovao vrstu govora s obzirom na ono što se dogodilo, 
razlikovanje „alegorije u riječima” i faktualne alegorije unio je Toma Akvinski - ključan autor za skolastičke poetike. ${ }^{18} \mathrm{U}$ vremenu kada biblijska egzegeza konstituira teološku znanost u sâmom njezinu načelu (de Lubac 1998: 13 i de Lubac 2000: 77), ${ }^{19}$ sasvim je razumljivo da Akvinski članak o sacra theologiae u svojoj Teološkoj sumi završava objašnjavanjem strukture kršćanske egzegeze. Riječ je o topičkom mjestu patrističke i medievalne kršćanske kulture, koje je Aleksandar iz Danske na kraju prvog poglavlja (De introductoriis scientiae theologicae) svoga djela Rotulus pugillaris (oko 1260) - i to nakon što je izložio prvo pitanje (o teološkoj znanosti) Akvinčeve Sume - sumirao sljedećim dvostihom: „Littera gesta docet, quid credas allegoria, / moralis quid agas, quid speres anagogia.”20

Najelementarniji smisao (sensus litteralis) u kojem Biblija može biti shvaćena, rekapitulira Akvinski, povijesni je ili doslovni smisao. Na njemu se temelje drugi smislovi, koje Akvinski okuplja pod jedinstvenim duhov-

kao u Knjizi o kraljevima, i figurativni govor, kao u Pjesmi nad pjesmama: "genus locutionis rerum omnino gestarum sicut in Regnorum libris” - „genus locutionis figuratarum rerum, sicut in Cantico canticorum." Gen. litt., VIII, c. 1, n. 2 (PL, XXXIV, 371). Hugo od Svetog Viktora je u Didascaliconu napisao da u Bibliji postoje neka mjesta koja se ne mogu čitati literalno: „Sunt quaedam loca in divina pagina, quae secundum litteram legi non possunt." VI, c. iii (PL, CLXXVI, 801 B). Kršćanski su autori zapravo samo ustvrdili da u Bibliji postoje mjesta koja ne možemo uzeti „literalno”, već „figurativno”, ali da pritom „figurativno” značenje teksta i nadalje ostaje „literalno”, a ne „alegorijsko” (de Lubac 2000: 56).

18 Iako skolastika ima više struja (okamizam, averoizam, skotizam), utjecaj Tome Akvinskoga na skolastičke poetike veći je negoli se mislilo: on je proporcionalan njegovu autoritetu među dominikancima (o čemu govori Acta capitulorum generalium ordinis praedicatorum) (Greenfield 1981: 44). Njegova distinkcija između teologije i pjesništva (koje za Tomu ne prelazi literalno značenje) ključan je alat usmjeren opovrgavanju humanističkog izjednačavanja Biblije i pjesništva na temelju alegorije. O Tominu utjecaju na Marulića usp. Parlov 1996, Parlov 1998, Parlov 1999 i Novaković 2005: 56.

19 H. de Lubac je uvjerljivo pokazao da biblijska egzegeza nije bila samo jedna specijalizirana teološka disciplina, već teologija sâma. U djelima patrističkih pisaca rijetko se mogu naći argumenti zasnovani samo na filozofijskim (logičkim) osnovama. Biblijski tekstovi bili su osnovica pri izražavanju središnjih dogmi i moralke. Toma u prvom pitanju svoje Sume izraze sacra doctrina i Sacra Scriptura koristi naizmjence, kao sinonime. U In Boet, de Tr., q 5, a. 4. Toma piše: Theologia quae sacra Scriptura dicitur." Unatoč dvanaestostoljetnoj i trinaestostoljetnoj proliferaciji Summa i Quaestiones sacra doctrina i sacra scientia ostale su usko vezana uz sacra pagina (de Lubac 1998: 74).

20 Aleksandrova knjiga Rotulus pugillaris svojevrsni je teološki kompendij koji se sastoji od petnaest poglavlja. Svako poglavlje završava sumarizacijom sadržaja u nekoliko stihova. Međutim, stihovi koji sumiraju klasično egzegetsko načelo postali su poznati zapravo po tumačenju Poslanice Galačanima Nikole iz Lire u njegovoj Postilla (oko 1330). 
nim smislom (sensus spiritualis) (Summa Theologica I, q. 1, a. 10 c). Doslovni smisao izjednačuje se sa sâmim događajima - u značenju „svete povijesti”. To znači da likovi i činjenice „svete povijesti” posjeduju vrijednost znaka, te pored svoje povijesne istine i zbilje posjeduju „simboličku zbilju”. Bog je uredio događaje "svete povijesti” tako da oni budu označitelji (Quodl., VII, 6,16 c). Očito, nije riječ o sveopćem alegorizmu (prisutnom u velikim pučkim enciklopedijama 12. i 13. stoljeća), jer jedino događaji i likovi „svete povijesti" imaju vrijednost znaka. ${ }^{21}$ Književnu metaforu Akvinski definira na drugi način - govori o paraboličkom smislu (sensus parabolicus). Pjesničke metafore imaju samo jednu funkciju - da znače. ${ }^{22}$ To znači, tumači Umberto Eco, da su pjesnička tvorevina i njezino značenje tako ujedinjeni da jedno odmah povlači za sobom drugo. Njihovo razumijevanje stoga pripada doslovnom smislu: nije nužan napor da bi se otkrio metaforički smisao, jer se on očituje paralelno s tvorevinom (Quodl. VII, 6, 16, ob. 1 i ad 1). Akvinski nudi i primjer: ponekad je u Bibliji Krist prikazan u liku jaganjca. Taj jaganjac nije nešto što postoji (u ovom slučaju), nego je to imaginarna sličnost, proizvoljno i konvencionalno postavljena da nešto znači. Kad bi se radilo o činjenicama koje simboliziraju božanske ili buduće stvari, imali bismo duhovni smisao - no u ovom slučaju imamo samo doslovni (Quodl., VII, 6, 15 c). Dakle, alegorijski je smisao smisao neke stvari i njega je potrebno otkriti istraživanjem sâme stvari. Parabolički je smisao smisao slike koja se toliko prilagodila i proporcionalizirala svom značenju da se predstavlja kao jedno s njim (Summa Theologica I, q 1, a 10, ad 3; usp. Eco 2001: 174-175).

Iz naznačena Akvinčeva tumačenja proizlazi i skolastičko klasificiranje književnosti (poetica): infima doctrina (Summa Theologica I, q. 1, a. 9, obj. 1). ${ }^{23}$ Književnost je pak infima doctrina jer „sadrži najmanje istine” (Comm.

21 Prema Tomi, u svim „ljudskim znanostima” ne može se naći ništa doli literalno značenje (Quodl., VII, 6, 16 c).

22 Akvinski u komentaru Libri quatuor sententiarum Petra Lombardskog napominje da je pjesništvo oštro odvojeno od teologije, jer su metode obje znanosti potpuno različite. Pjesništvo se bavi stvarima koje zbog pomanjkanja istine (propter defectum veritatis) ne mogu biti spoznate razumom. Teologija se, s druge strane, bavi stvarima koje nadilaze razum. Buduće da se obje znanosti bave područjima koja su onkraj racionalnoga, zajednički im je simbolički način. No, unatoč tome teologija i pjesništvo nisu identični jer su im sadržaji drugačiji (1 Sent. prol. 1.5 c).

23 Da je književnost „najniža” spekulativna znanost tvrdio je i Gerolamo Savonarola: „, [...] inter omnes scientias speculativas infima." (De divisione scientiarum, Firenca, 1946, str. 804) 
in IV Sent., Prologus, q. 1, a. 5, obj. 3). ${ }^{24}$ Ovakvom zaključku, oštro su se suprotstavili humanisti. Upirući se na Jeronima i naročito na neka arhetipska loci u Augustinovu opusu (Contra mendacium 13. 28; Soliloquia 2. 10. 18, 19; De doctrina Christiana 3. 10. 14; 2. 6. 7-8; 2. 440. 60) humanisti su u svojim poetičkim traktatima ekstendirali patrističko-medievalnu egzegezu zasnovanu na (tri) četiri smisla na pjesništvo (usp. Greenfield

Navedeno prema: Greenfield 1981: 256. Za Savonarolu je pjesništvo dio racionalne filozofije, a njezin sadržaj je exemplum. Dakle, on ne dobacuje pjesništvo u potpunosti, već samo humanističko-neoplatoničko i retoričko tumačenje pjesništva. Poput Tome, Savonarola je također tvrdio da samo Biblija ima duhovno ili alegorijsko značenje. Pjesničke metafore i parabole imaju samo literalni smisao: „Nullam ergo scientiam praeter Sacram Scripturam proprie \& vere sensum habet spiritualem. Nam sensus metaphorarum poeticarum est literalis tantum, sicut sensus parabolarum Evangelicarum." (De divisione scientiarum, Firenca, 1946, str. 822) Navedeno prema: Greenfield 1981: 256.

24 Zašto Toma govori o infima doctrina? - pita se U. Eco. Čini se da su motivi očigledni. Ponajprije, pjesničko umijeće prikazuje se kao zamisao o umjetničkoj tvorevini (ratio factibilium) povezano sa stanovitim činjenjem: učenje s jedne strane (kao invencija i izraz činjenica, događaja, osjećaja, mišljenja) i rad s druge strane. Spram čiste spekulacije ono se postavlja svakako na nižu stepenicu. Čini se da slijedeći tradiciju koja hijerarhizira čovjekovu djelatnost, poimanje pjesničkog modusa nije pokazatelj prezir, već klasifikacijska vrijednost. Kada je riječ o definiciji pjesničkih stvarnosti koje konstitucionalno pogađa stanoviti defectus veritatis (nedostatak istine), rješenje problema ne pokazuje se jasnim. Najprihvatljivije rješenje nesumnjivo je ovo: zbilja što ih označuje pjesničko umijeće fantastična je činjenica, bajkovita zbilja („poeta utitur metaphoris propter repraesentationem; repraesentatio enim naturaliter homini delectabilis est” - „pjesnik se služi metaforama radi slikovitosti; naime, slikovitost je po naravi čovjeku ugodna" Summa Theologica I, 1, 9 ad 1). U takvom slučaju pjesnik nastoji prikazati nešto nepoznato svojoj publici, nepoznato zato što je nepostojeće ili nikad nije viđeno, a neshvatljivo zato sto se pojmovno ne može definirati, i to ne zato što bi tu bila riječ o zbilji koja po sebi izbjegava svako poimanje nego zato što je pojmovna spoznaja definicija po rodovima i vrstama. Pjesnik, dakle, predočuje tu zbilju (koja posjeduje u sebi, barem za nas, neki nedostatak istine) predodžbom, a predodžba se može ostvariti samo usporedbom. Ako ne spoznamo točno formu nečega (ili zato što ne postoji, ili zato što smo nesposobni za znanstvenu pažnju), ne možemo a de ne reproduciramo formu nečega drugoga što nam je poznato i putem čega nastojimo upoznati zbilju koja nas zanima. Tako dobivamo pjesničku usporedbu u kojoj je nedostatak istine teoretsko ograničenje (koje ne remeti njezinu vrijednost), a ne božanska dubina. To je rečeno da bi se pojasnilo ono što je moglo biti kamen spoticanja: radilo se, međutim, o činjenici koja nije od odlučujućeg značenja, a Toma ju je naveo samo kao usporedbu. Odnosno, ako se morala opravdati nužnost metaforičke (alegorijske) predodžbe vjerskih otajstava, on kaže: budući da ti misteriji nadilaze naše sposobnosti razumijevanja, nastojimo ih sebi prikazati pomoću sličnosti, kao što pjesnik skriva u metafore one stvari koje zbog njihove nerealnosti možemo shvatiti jedino ako su tako prevedene i alegorizirane (Eco 2001: 171). 
1981: 30-35). ${ }^{25}$ Dante (Covivio 2.1), Boccaccio (De genealogiis deorum), ${ }^{26}$ zatim Cristoforo Landino (Dante con l'espositioni di Cristoforo Landino, Venecija, 1578), ${ }^{27}$ pa i platoničari Marsilio Ficino, Giovanni Caldiera, Pico della Mirandola zanemarili su oštar rez između „alegorije u riječima” i faktualne alegorije, klasičnog i kršćanskog tumačenja koji su uspostavili patristički i medievalni autori.Iz naznačene patrističko-medievalne tradicije tumačenja alegorije - što je za osnovnu tezu ovog rada (da Marulić ne bira „srednji put”) ključno - proizlazi da je nepomirljivost patrističko-medievalnog i stoičko-platoničkog, odnosno skolastičkog i humanističkog shvaćanja, koji su oni naoko koegzistirali, ${ }^{28}$ tako duboka da se pjesničke pričice (odnosno mitologija) ne mogu opravdati čak ni tropološkim tumačenjem

25 Da je Marulić poznavao i podjelu na tri smisla (historico, morali, spiritali) vidljivo je u Evandelistaru I: I, 8.

26 Boccaccio je smatrao da egzegetsko načelo „četiri smisla” služi također da bi se otkrila pjesnička istina. Pjesnička djela se, naime, daleko od opskurnosti, mogu uvijek tumačiti (Gen. 14. 12). Nakon što je ustvrdio da fikcija nije isprazna besmislica, opisao je četiri vrste fikcije: fikcija bez ikakvih povijesnih događaja (Ezopove basne), fikcija pomiješana sa istinitim događajima, događaji koji su se zaista dogodili i stare priče koje ne sadrže nikakve događaje. Prva tri tipa, napominje Boccaccio, nalaze se i u Bibliji (ilustracija za prvi tip je konferencija drveća koja biraju svojega kralja [Knjiga sudaca 9, 8-15], drugom tipu pripada niz biblijskih tekstova koji se nazivaju „figure”, Isusove parabole ilustriraju treći tip (Gen. 14. 7, 8).

27 C. Landino je alegorijsku interpretaciju primijenio na Homera: prvo se ispituje što se dogodilo (historijski aspekt), zatim zašto se dogodilo (etički aspekt), postoje li kakve proturječnosti (analoški aspekt), konačno se istražuje što je skriveno pod figurae (Disputationes Camaldulenses, Lib. III, 68).

28 Da su skolastika i humanizam koegzistirali, da je između medievalne i humanističke kulture postojao kontinuitet isticali su: Curtius 1948, Kristeller 1961 i Ullman 1963. C. C. Greenfield je pokazala da su i jedni i drugi svoje stavove zasnivali na istim topičkim mjestima aristoteličke tradicije. Uz latinsku retoričku tradiciju (Ciceron, Kvintilijan, Horacije) i neoplatonizam (platonizam deriviran iz pitagorejske estetike proporcije i broja koja pretpostavlja da stvorenje reflektira harmoničnu proporciju nebesa [u Makrobijevim Saturnalijama pjesnik ima božanski uvid u takvu harmoniju; on stoga izražava ljepotu harmonične proporcionalnosti metaforama i simbolima] i ideja poeta vates [pjesnik prorok] usko povezana s pjesničkim ludilom) temeljna je tradicija koja je oblikovala humanizam homerska alegoreza koja je pomirivala Homera i Platona. Skolastiku je ponajprije oblikovala aristotelička tradicija. Međutim, aristotelička tradicija nije bila strana niti humanistima: prva knjiga Aristotelove Metafizike bila je izvor topoa i za humaniste i za skolastike: prvi su iz nje izvukli teoriju da je pjesništvo teologija, najstarija i božanska znanost, koja koristi alegoriju kao i Biblija, drugi su iz istih pasusa razvili teoriju da pjesništvo nije teologija, da ne koristi alegoriju na isti način kao i Biblija te da je daleko od toga da je božanska znanost - štoviše, da je najmanja od svih znanosti (Greenfield 1981: 17-48). 
kojima se pokušavaju aktualizirati kršćanske krjeposti. Naime, kršćanska tropologija crpi svoje primjere (exempla) iz otajstva (mysterium) povijesnih događaja. ${ }^{29}$ Riječ je o otajstvenom smislu morala (mysticus moralitatis sensus), ${ }^{30}$ o „otajstvenoj tropologiji” koja se razvila napose u redovničkoj egzegetskoj tradiciji (Bernard iz Clairvauxa, Godfrey iz Admonta, cisterciti Isaac iz Stellae, Guerric iz Ignyje, Henry iz Marcyja). Alegorija se stoga više nije razlikovala od tropologije: otajstvo i moral su se ujedinili u jedinstvenu mističnu viziju punu slatkoće. ${ }^{31}$

Dakle, ukoliko alegorija razvija dogmu, utoliko ona ne razvija bilo kakvu moralku, već kršćansku antropologiju i duhovnost koja proizlazi iz dogme. Otajstvenim djelima koja su učinjena (facta mystica) naznačuju se djela koja trebaju biti učinjena (facienda mystica). Takav „program” naznačio je već Pavao: „Što je nekoć napisano, nama je za pouku napisano” („Quaecumgue scripta sunt, ad nostram doctrinam scripta sunt”); „Ali nije samo za nj napisano [...] nego i za nas” („Non est autem scriptum tantum propter ipsum [...] sed et propter nos”) (Rim 15, 4; 4, 23) i: „To bijahu pralikovi naši: da ne žudimo za zlima kao što su žudjeli oni; Sve se to, kao pralik, događalo njima, a napisano je za upozorenje nama, koje su zapala posljednja vremena” („Haec autem in figura contingebant illis, ${ }^{32}$ scripta sunt autem ad correptionem nostram, in quos fines saeculorum devenerunt") (1 Kor 10, 6. 11). ${ }^{33}$

29 „Omnis ejus opera, aut mysteria sunt rerum praefiguratarum, aut exempla virtutum.” Paschasisu, In. Matt., XII (PL, CXX, 910-911); „Sumamus et nos de mysterio ejus moribus nostris exemplum.” Bernard, De div., s. 3 (PL, CLXXXIII, 684 A); „et ut plenius noveris conceptum virginis non solum esse mysticum, sed et moralem, quod sacramentum est ad redemptionem, exemplum quoque tibi est ad imitationem; ut manifesete evacues in te gratia sacramenti, si non imiteris virtutem exempli." Guerric, De annunt., s. 2, De Verbi incarn. in Maria et in anima fideli, $n .4$ (PL, CLXXXV, 122-123).

30 „Quidquid enim legimus vel intelligimus, totum ad interioris hominis usum conferre poterimus. Si ergo totam veteris ac novi Testamenti seriem enucleatius perscrutari velimus, mysticum moralitatis sensum inditum ubique invenimus." Godfrey iz Admonta, $h$. 30, in annunt. 4 (PL, CLXXIV, 765 B).

31 „Licet sensus iste allegoricus sit, tamen et redolet moralitem, ipsaque allegoriarum mysteria non carent moralitatis dulcedine." Godfrey iz Admonta, H. dom. 15; PL, CLXXIV, 105 B.

32 Gorenavedene Apostolove riječi Marulić je na početku svojega alegorijskog tumačenja Davidijade (Tropologica Davidiadis expositio) naveo, čini se, po sjećanju: „Omnia illis contingebant in figuram" (Marulić 1984: 453).

33 Škola od Svetoga Viktora uči da se u Bibliji nalaze dvije stvari za kojima treba tragati: spoznaja istine (cognitio veritatis) i oblik vrline (forma virtutis): „In omni autem Scriptura aut 
Očito: daleko od toga da je izvanjska i inferiorna „dubljim smislovima” alegorije, tropologija je čak svojevrsni vrh alegorije. ${ }^{34}$

Da je Maruliću naznačena patrističko-medievalna egzegetska tradicija, barem u osnovnim crtama, bila poznata, između ostaloga, svjedoči Biblija koju je posjedovao (Biblia latina cum comento). Riječ je o Bibliji na latinskom jeziku koju je 1489. godine tiskao Boneto Locatelli, svećenik i tiskar iz Bergama, za mletačkog izdavača Ottaviana Scota starijega. Ta je Biblija sadržavala, uz osnovni biblijski tekst, komentare (Postilla) Nikole iz Lire koji je naglašavao upravo važnost doslovnog značenja (sensus litteralis). ${ }^{35}$ Da mu je redovnička teološka tradicija (barem Bernard iz Clairvauxa) također bila poznata, s pravom se, smatram, pretpostavlja. ${ }^{36}$

cognitio veritatis quaerenda est, aut forma virtutis. Primo studio historia et allegoria proponitur; secondo tropologia [...]" (Miscell. I, 13; PL, CLXXVII, 484-485). Usp. Abelard (PL, CLXXVIII, 94 C); Richard iz Svetog Viktora (PL, CLXXV, 340, C); Ivan iz Salisburyja (PL, CXCIX, 666, B).

34 „Historia et parabolis nutrimur; allegroia crescimus; moralitate perficimur.” Hugo iz Rouena, Dial., VII, c. xi (PL, CXCII, 1243 C); „Triplex intelligentia - Diversa praebet fercula [...] - Alunt parvos historica - Pascunt adultos mystica - Perfectorum ferventi studio Suscipitur moralis lectio." Abelard, PL CLXXVIII, 1775-1776.

35 J. S. Preus je istaknuo da je Nikola iz Lire zapravo razvio koncept „dvostrukog literalnog smisla” (duplex sensus litteralis). Navodeći riječi iz Prve knjige ljetopisa 17, 13: „Ja ću njemu biti otac, a on će meni biti sin” i njihovo novozavjetno „ispunjenje”: „Ti si sin moj, danas te rodih" (Heb 1, 5), Nikola tvrdi da oba teksta imaju literalno značenje (prvi se referira na Solomona, drugi na Isusa Krista). Drugim riječima, postoji „židovski” i „kršćanski” literalni smisao (Preus 1969: 78). Osim Nikolinih komentara latinska Biblija iz 1489. godine sadržavala je i kritičke dodatke (Additiones) Pavla de Sanata Marije iz Burgosa, Responsiones (Replicationes) Matthiasa Doringa u obranu Nikolinih komentara, zatim prologe (Prologues) pojedinim biblijskim knjigama sv. Jeronima i Expositiones Jeronimovim prolozima Williama Brita - a Marulićev primjerak, dakako, i Marulićeve marginalije (Posset 2013: 48-52).

36 Z. Pandžić smatra da je prijevod Bernardinova (ili možda Pseudo-Bernardinova) Liber de modo bene vivendi, ad sororem (Nauke svetoga Bernarda k sestri svojoj) u rukopisu HAZU I b 55 Marulićev, kao i Govorenje sv. Bernarda od duše osujene (prijevod pjesme Meditatio de passione Jesu Christi). Naime, poznato je, ističe Z. Pandžić, da je Marulić svojim proznim djelima na kraju i(ili) na početku nastojao umetnuti po jedan ili više pjesničkih sastavaka (Pandžić 2009: 38-49). Pandžićevi uvidi korespondiraju s onima J. Badalića. On je, naime, na temelju usporedbe Marulićevih latinskih autografa (Collecta, Marulićev autograf koji je Ferdo Šišić pronašao u Narodnoj biblioteci u Rimu, Marulićeve bilješke na marginama pojedinih inkunabula koje su bile Marulićeva svojina, autograf epa Davidijada pronađen u Nacionalnoj biblioteci u Torinu) i rukopisa Lucićeva Vartla došao do zaključka da je Govorenje sv. Bernarda od duše osujene (također i Skazanje od nevoljnoga dne od suda ognjenoga napokonji koji ima biti i Život blaženoga svetoga Ivana Karstitelja), zapravo Marulićev autograf (Badalić 1967). F. 
IV.

Opis tradicijskog okoliša Dijaloga, prisjetimo se, Lučin zasniva na sljedećoj rečenici: „Pa ipak, pjesnici štošta izmišljaju pod čime hoće da se krije alegorija bilo prirode bilo značaja, bilo da je riječ, štaviše, o zamračenu značenju u vezi s nekim stvarnim događajem." Riječ je o tri načina tumačenja mitova: povijesnom/euhemerističkom, naturalističkom i moralističkom. Maruliću je zbog „općeg duhovnog profila” zatim zbog „pogleda na ulogu i svrhu književnosti” i, konačno, zbog toga „što se takvo tumačenje dodiruje $s$ jednim o četiriju načina svetopisamske alegoreze: $s$ iznalaženjem tropološkog smisla", ustvrdio je Lučin, najbliži upravo treći, moralistički modus alegoreze. U prvi mah uistinu se čini da je tako. Tumačenje sedmog Herkulovog djela izvršenog na zapovijed (s Krete je na Peloponez dovezao bika u kojega se zaljubila Minojeva supruga Pasifaja te ga je iznio pred Euristeja) ilustrativan je primjer tropologizacije:

„A ono što je bika u koga se Pasifaja bila zaljubila dovezao s Krete na Peloponez i iznio ga pred Euristeja - ako gledaš samu stvar, nema razloga da ga osobito hvališ, no ako se zamisliš u otajstvo samoga čina, nemalo će ti upravo to pomoći da si urediš vladanje u životu. No da bi takva korist uslijedila, ovako će nam valjati to protumačiti: bik je, očito, naše tijelo, Pasifaja duša, Herkul razum, a Euristej Bog. A naša duša - čini se odviše ljubi svoje tijelo tada kad ugađa njemu koje je sklono i podatno uživanju naslada. Razum se pak, pokoravajući se Euristejevim, tj. Božjim zapovijedima, trudi da naše tijelo prenese od poroka ka kreposti, kao što je taj bik bio prevezen $s$ Krete na Peloponez. A kad učinimo prijelaz od zla k dobru, tada se sami pravo dajemo Bogu, kao što se kaže da je Herkul s bikom izašao pred Euristeja. No tako se vlada pravovjerni kršćanin koji sluša Božje zapovijedi, a ne Herkul koji postupa po nalogu smrtnoga čovjeka." (LMD I: 78-79)

\footnotetext{
Fancev smatra da se Maruliću može atribuirati i prijevod pjesme sv. Bernarda Rhythmica oratio ad unum quodlibet membrorum Christi patientis et a cruce pendentis, koji se nalazi i u Vartlu (pod naslovom Molitva svetoga Bernarda: Salve meum salutare, što je krivo; trebalo bi: Salve mundi salutare) i u krnjem obliku (nema naslov i završetak) u Osorsko-hvarskoj pjesmarici (Fancev 1993: 37-39).
} 
„Illud autem, quod taurum, cuius amore Pasiphe capta fuerat, a Creta ad Peloponessum aduexerit obtuleritque Euristeo, si rem spectes, nihil est, quod magnopere laudes, sin rei mysterium inspicias, haud parum id quidem iuuabit ad uitę morumque institutionem. Tale autem commodum ut sequator, ita interpretari nobis conueniet: taurum uidelicet corpus nostrum esse, Pasiphen animam, Herculem rationem, Euristeum Deum. Corpus suum anima nostra tunc nimium diligere uidetur, cum eidem in hauriendis uoluptatibus prono propensoque blanditur. Ratio autem Euristei, hoc est, Dei iussis obtemperans, transferre nititur corpus nostrum de uitio ad uirtutem, sicut taurus iste de Creta transuesctus est ad Peloponessum. Cumque de malo ad bonum transitum fecerimus, tunc recte nos ipsos offerimus Deo, quemadmodum Hercules cum tauro obtulisse se dicitur Euristeo. Sed hoc fidelis Chrisitani est, Dei pręcepta obseruantis, non Herculis ex hominis mortalis iussione pendentis." (LMD I: 117-118)

Ali - valjda ne slučajno - upravo kada mu je Pjesnik izložio sedmo Herkulovo djelo izvršeno na zapovijed, Bogoslov je ustvrdio: „[...] smatram da je sve to uistinu samo priča i da su to drevni pjesnici izmislili [...]" („Tametsi cuncta hęc quidem fabulosa et a priscis uatibus conficta esse rear [...]" (LMD I: 66/106). Takav nedvosmislen stav Bogoslov ponovno iznosi kada se osvrće na Herkulovo djelo silaska u podzemlje i izvlaćenja u gornji svijet troglavoga Kerbera: „sve je to samo priča [...]” („totum hoc fabulosum est [...]" (LMD I: 80/120). Pretpostavljam da niti ovdje nije riječ o pukom slučaju. Naime, upravo je Herkulova katabaza bila središnja točka u zasnivanju ideje da Herkul bude figura Christi. Konačno, na samom kraju Dijaloga Bogoslov iznosi svoju nakanu:

„To sam htio da ti bude znano da bi u raspoznavanju istine o onom o čemu je riječ radije slijedio naše bogoslove negoli svoje pjesnike i da bi, držeći se čvrsto propisâ i zasada svete Crkve, prezreo ispraznost takvih pričica." (LMD I: 92)

„Hoc tibi notum esse uolui, ut theologos nostros potius quam poetas tuos in dignoscenda rerum ueritate sequaris et Ecclesię sanctę pręceptis institutionibusque adhęrendo fabellarum contemnas uanitatem." (LMD I: 130) 
Na dva je mjesta Bogoslov nešto blaži. Nakon što mu je Pjesnik ispričao svih dvanaest Herkulovih pothvata koje je učinio na zapovijed, pomirljivo je pretpostavio: „[...] recimo da je istinito [...]” (,[...] ut concedam uera fuisse [...]") (LMD I: 68/107). Kada je pak započeo uspoređivanje Herkulovih djela s djelima kršćana, ponovio je: „Ali dopustimo da je sve što se o njemu kazuje istinito i da u tome nema nikakve bajke!” („Sed concedamus cuncta, quę de illo feruntur, uera esse nihilque in his fabulosum haberi” (LMD I: 75/114). ${ }^{37}$ Dakle, dvama je "mekšim” stajalištima Bogoslov omogućio razgovor, dok je na početku, u sredini i na kraju neumoljiv: ono što mu pripovijeda Pjesnik puka je priča, štoviše pričica (fabula, fabella). Jasno je stoga da su stajališta Pjesnika i Bogoslova nepomirljiva: Pjesnik, s jedne strane, smatra da je priča o Herkulu historia („Longa est historia” LMD I: 104), Bogoslov, s druge strane, smatra da je priča o Herkulu fabula („[...] fabulam dixisti [...]” LMD I: 123), a da se historia nalazi u Bibliji i da se nju „dohvaća” per fidem (Bogoslov se na vjeru poziva odmah nakon što je spomenut „razum” [ratio ${ }^{38}$ - što, čini se, ukazuje na mainstream katoličke teologije: fides quaerens intellectum [Anselmo], odnosno da nije riječ o fideizmu).

37 Istina koju ističe Marulić nije istina koja je u skolastičkoj literaturi zadobila formulaičan izraz adaequatio rei et intellectus, već Biblija, odnosno „sveta povijest”. Nju se prihvaća vjerom. Stoga će Bogoslov na Pjesnikove riječi: „Kako nađoh da piše, tako i pripovijedam. Ako je izmišljeno, upiši, molim te, u grijeh onima koji su to napisali, a ne meni” (,Sicut scripta reperi, ita narro. Si ficta sunt, illis, quęso, uitio uertas, qui scripsere, non mihi) odgovoriti rezolutno: „I tebi također, ako smatraš da je istinito.” („Immo etiam tibi, si uera fuisse censes") (LMD I: 66/106) (usp. Institucija VI, 13). A. Zlatar pitanje o istini, u svojoj analizi Davidijade, izmješta iz suvremenog horizonta referencije. Referencija se, kada je riječ o istinitosti biblijskog teksta, napominje A. Zlatar, premješta unutar granica sâmog teksta: novozavjetna pripovijest ima za referenciju starozavjetnu, a istinit je odnos između njih, smisao koji nastaje njihovim združivanjem (Zlatar 1991: 71). Da se novozavjetni tekstovi referiraju na starozavjetne (Stari zavjet je figura Novog), Marulić je pokazao kada dva stupa koja Herkul podiže kod Gada tumači kao dva Pisma - Stari i Novi zavjet, pri čemu je Stari figura Novog (LMD I: 89/126). Međutim, kršćanski autori istinu biblijskog teksta ne svode samo na unutartekstovne referencije (Stari i Novi zavjet), već snažno ističu povezanost teksta s izvantekstovnim događajima. Dakako, kršćanski autori itekako su bili svjesni složenosti odnosa teksta i događaja (usp. Nemetz 1959).

38 „Zahtijevam samo da na upite odgovaraš u skladu s razumom.” (Tantum, ut interrogatus rationi consentanea respondeas, uolo.”) LMD I: 71/111. „[...] smatram da ništa nije većma sukladno i primjereno zdravu razumu.” („[...] immo nihil rationi magis congruum atque conueniens esse reor." LMD I: 73/112. 
„Uostalom, budući da sam te upoznao kao kršćanina, ne sumnjam da ćeš više vjere pokloniti onomu pismu koje nam je dano od Boga negoli gluposti onih koji su smatrali da Bog nije jedan [...]" (LMD I: 73)

"Cęterum, cum te Christianum esse noueram, non dubito, quin scripturis diuinis nobis datis plus fidei pręstes quam illorum fatuitati, qui non unum Deum esse arbitrati sunt [...]" (LMD I: 112)

Pjesnik na to odgovara: „Jer kad njemu ne bih vjerovao (Pismu - op. K. Š.), ne bih bio kršćanin” („Nisi enim ei crederem, Christianus non essem”) (LMD I: 73 i 112). Upravo u ovom stajalištu (vjera u biblijsku povijest kao istinu) zrcali se nepremostiva razlika između stoičko-platoničkog i patrističko-medievalnog, odnosno humanističkog i skolastičkog shvaćanja alegorije/alegoreze. Za prvo shvaćanje mitske pričice samo su „ljuska” koja se supstituira „jezgrom” (jer je istina idea koja se dohvaća umom), za drugo je doslovni ili historijski smisao (Biblija) temelj na kojem se gradi tumačenje i koji alegorezom nipošto ne smije biti odbačen (jer je istina historia koja se dohvaća vjerom). „Kršćanski pjesnik”(LMD I: 124) - točnije epik, jer o njemu je u Dijalogu riječ - za građu svoga epa mora uzeti ono što pripada povijesnom, odnosno Bibliji, a koje „dohvaća” per fidem. Upravo to ga legitimira da bude kršćanski pjesnik - što je Marulić pokazao Juditom i Davidijadom. Za prototekst Judite u posveti Dujmu Balistriliću, kaže da je historija („Sih dan svetih korizmenih, počtovani u Isukarstu gospodine i kume moj dragi dom Dujme, privraćajući ja pisma Staroga testamenta, namirih se na historiju one počtene i svete udovice Judite i preohologa Oloferna, koga ona ubivši, oslobodi svu zemlju israelsku jur od nadvele pogibili.") (Marulić 2018: 107). ${ }^{39}$

39 R. Pšihistal ističe da ,jasna žanrovska oznaka (historija) koju Marulić primjenjuje na svoj prototekst ne ostavlja prostor dvojbi. Nije dakle riječ o pjesničkoj fabuli, niti o istinolikoj paraboli, već upravo o starozavjetnoj historiji koja se kao sveta i spasenjska fundamentalno razlikuje od svih ostalih profanih historija." Zatim napominje da uobičajena srednjovjekovna formula historije, kako se razabire u definiciji Izidora Seviljskog: historia est narratio rei gestae (Etymol. XII; PL 82, 122 B) ne pokriva u potpunosti područje svete povijesti jer biblijska historija ukljućuje sve tri vremenske dimenzije i ona, za razliku od profanih historija, ne mora prisezati na apsolutnu podudarnost između ispripovijedanog i učinjenog (pritom se R. Pšihistal referira na De ultimo Christi iudicio, LMD I: 181/246). Stoga zahtijevati potpunu podudarnost između zapisanog i učinjenog značilo bi, s jedne strane, izjednačiti svetu povijest $s$ bilo kojom profanom poviješću, dok bi, s druge strane, odreći 
Za Davidijadu u posveti kardinalu Grimaniju piše: „Prenio sam u stihove djela kralja Davida držeći se povijesti njihove kako je izložena u svetim knjigama, za koju ne sumnjam da je istinita” („Dauidis regis gesta uersibus expressi historiam secutus, quam in sacris proditam codicibus ueram esse non ambigo.") (Marulić 1984: 19 i 267). ${ }^{40} \mathrm{Na}$ samom kraju Davidijade (XIV, 417424) dolaze sljedeći stihovi: „Nije učeni meni Apolon pomagô u pjesmi / A ni Helikon ni skup od devet slavnih sestara, / Nego je Sveti Duh što s eterskih siđe visina / Moj rasvijetlio um božanskim svjetlom i dao / Meni da opjevam - ne izmišljotine pjesničke čudne / Niti u što se sve preobrazuju ljudi i bozi, / Nego što sam ko vjernik, osvjedočen knjigama starim, / Crpao iz njih i kušo maštovito iznijet u spjevu.” („Haec mihi cantanti non doctus fauit Apollo, / Non Helicon, non turba nouem celebrata sororum, / Sed sacer aetheria delapsus spiritus arce / Impleuit nostram diuino lumine mentem / Et uersu memorare dedit non ficta poetum / Prodigia aut uarias hominum diuumque figuras, / Sed quae nostra džfides scriptis testata uetustis / Hausit et arguto conata est promere cantu.") (Marulić 1984: 201-201 i 449-450) (usp. Davidijada I, 240-244 i VI, 108-109). Dakako, pretvaranje predloška u književni tekst nipošto ne znači dokidanje temeljnog (povijesnog) modusa predloška, ali nije riječ niti o pukom parafraziranju koje se oslanja na antičku retoričku tradiciju parafraziranja. Kršćanski epičar ponajprije se oslanja na crkvenu tradiciju parafraziranja (Springer 1988: 9-14). ${ }^{41}$

starozavjetnim knjigama svaku historijsku vjerodostojnost značilo izjednačiti ih $\mathrm{s}$ pjesničkim pričicama. Za patrističke i medievalne autore jedinstvenost Božjeg nadahnuća kao i poučavajuće spasenjska funkcija Biblije, napominje R. Pšihistal, „vezivni su članovi među pojmovima littera i historia. To znači da se biblijska povijest ne mora nužno sic et simpliciter podudarati s historijski i vjerodostojno dogođenim da bi bila istinita. Ništa u Bibliji nije zabilježeno bez spasenjsko-poučavajuće funkcije i viših implikacija koje se kriju ili u samim činjenicima ili u njihovu zapisivanju. Maruliću je stoga, zaključuje R. Pšihistal, dopušteno intervenirati $\mathrm{u}$ historijsko-doslovnu razinu izabrane svete historije, a da pritom ne naruši njezin historijski dignitet pa ni njezino mjesto u svetopisamskome kanonu." (Pšihistal 2002: 179-180).

40 A. Zlatar napominje da Marulićev historiam secutus treba shvatiti ne samo kao teološki ispravan put već i kao naracijski naputak (vjernost biblijskom tekstu iskazuje se narativnim postupcima: usustavljivanjem pripovijednih sekvenci - povezivanjem „jezgri” (R. Barthes) zajedničkih primarnom i sekundarnom tekstu (Zlatar 1991: 30). Ovdje je, čini mi se, vrijedno uputiti na tekst nesigurne atribucije Od istorije Estera, koji A. Kapetanović generički određuje kao versificiranu biblijsku pripovijest, jer već naslovom upućuje na Marulićevu poetičku koncepciju zasnovanu na biblijskoj egzegezi (usp. Kapetanović 2011).

41 Da je Marulić u oblikovanju Davidijade „veći dužnik” kršćanskim epičarima Juvenku (Evangeliorum libri), Seduliju (Carmen Paschale) i Aratoru (De actibus apostolorum) nego 
Dosad rečeno još uvijek nije nikakav novum u interpretaciji Dijaloga. Ono novo proizlazi iz - naznačenog u III. poglavlju - uvjerenja patrističkomedievalnih autora (naročito u redovničkoj egzegetskoj tradiciji) da se pjesničke pričice ne mogu opravdati čak ni tropološkim tumačenjem kojima se pokušavaju aktualizirati kršćanske krjeposti, jer kršćanska tropologija crpi svoje primjere (exempla) iz otajstva (mysterium) povijesnih događaja. Marulić stoga, mislim, tropološko-moralističkim tumačenjem sedmog Herkulovog djela izvršenog na zapovijed ne pokazuje da „pjesničke pričice” postaju korisnima ako se tropološkim tumačenjem posve odbaci njihov doslovni smisao, već mu takvo tumačenje (kao, uostalom, i naturalističko tumačenje: primjerice, Neptuna tumači kao more; LMD I: 88/128) jednostavno služi kako bi pokazao da mu humanistička tropološka alegoreza nije strana - pa čak, možda, i da bi takvu alegorezu ironizirao (što se, možda, može naslutiti uporabom riječi otajstvo [mysterium] karakterističnoj za kršćansku tropologiju - za Herkulova djela [točnije, za djelo dovođenja bika u kojega se Pasifaja zaljubila s Krete na Peloponez]). Marulić, čini mi se, shemom nadmašivanja (Hercules supertus) ne iskazuje samo „dodatnu suzdržanost”, već zapravo odbacuje tropološko tumačenje „pjesničkih bajki i izmišljotina”. Držim da u prilog takvom tumačenju (da Marulić odbacuje i tropološko tumačenje u svrhu „uređivanja” kršćaninova života) idu i topička mjesta iz Institucija (I: II, 5) i Evanđelistara (I: III, 7) gdje doduše, nije riječ o razvijenoj kritici humanističkih tendencija ekstendiranja alegorije/alegoreze na mitologiju, već (za osnovnu tezu ovog rada bitnije) o odbacivanju antičke mitologije pri traganju za načinom „kako urediti vladanje u životu”, što, dakako, ne znači i nužno odbacivanje mitološkog rekvizitarija pri oblikovanju kraćih latinskih stihovanih sastavaka (epitafi, epigrami, himni).

Vergiliju, pokazao je D. Novaković (Novaković 2000). Oslanjajući se na istraživanja „biblijskog pjesništva” Maxa Wehrlija (Sacra Poesis. Bibelepik als europäische Tradition, 1963), Reinharta Herzoga (Die Bibelepik der lateinischen Spätantike, 1975) i Dietera Kartschokea (Bibeldichtung. Studien zur Geschichte der epischen Bibelparaphrase von Juvencus bis Otfrid von Weissenburg, 1975), žanrovsku oznaku „biblijski ep” za Davidijadu u marulologiju je uveo W. Baumann (Baumann 1984.). „Biblijski ep” je, prema M. Robertsu, sastavak pisan daktilskim (herojskim) heksametrom koji duguje "narativni kontinuitet biblijskom slijedu događaja” (Roberts 1985: 2). O generičkoj odrednici Davidijade usp. Zlatar 1991: 7-22. O uklopljenosti (doduše inovativnoj, naročito u etimologijama) Tropologica Davidiadis expositio u patrističku egzegetsku tradiciju usp. Palameta 2017. 
V.

Marulić se Dijalogom o Herkulu - posljednjim i najzamašnijim očitovanjem o naravi pjesništva (Novaković 2005: 53) - uključio u skolastičkohumanističke poetičke rasprave, ${ }^{42}$ čiju središnju os čine rasparave Mussato Giovannino iz Matove (Padova); Salutati - Dominici (Firenza); ${ }^{43}$ Fiano (Rim); Guarino Giovanni da Prato (Ferara). Fokalno mjesto mnogih humanističkih poetika bio Salutatijev De laboribus Herculis (Greenfield 1981: 130). Štoviše,

42 C. C. Greenfield je, nakon što je analizirala reprezentativne autore od Dantea do Bartolomea Fontiusa, izdvojila šest osnovnih karakteristika ranonovovjekovnih humanističkih i skolastičkih poetika (poetička pitanja redovito su promišljana u traktatima posvećenim drugim temama: povijesti, retorici i moralnoj filozofiji). Prvo, postoji tematski kontinuitet od radova ranih humanista do kraja petnaestoga stoljeća (osnovne teme su pjesništvo kao forma božanske elokvencije, alegorija koja omogućava užitak, povijesnu i filozofijsku mudrost, zatim platonički topos pjesničke mahnitosti, koji preuzimaju iz Iona i Fedra; humanisti se također, u nekoj mjeri, oslanjaju i na Aristotelovu Metafiziku - Poetiku su uglavnom poznavali posredno iz Averroësove parafraze - iz koje su derivirali sljedeće teme: a) pjesnik-teolog, b) pjesništvo je zasnovano na čuđenju - admiratio i c) filozofi - ljubitelji mitova - također su pjesnici; te su ideje uglavnom izolirali iz šireg konteksta i njima se služili da bi uvjerili skolastike da je njihov „učitelj” Aristotel također humanist). Drugo, humanistička poetička načela proizlaze iz „obrane pjesništva” (cilj humanista je bio „obraniti” vrijednost pjesništva, uglavnom „poganske” književne kulture, i pjesništvo postaviti u središte kurikula studia humanitatis). Treće, humanističke poetike ne prekidaju s medievalnom tradicijom (one se ne oslanjaju samo na cicerijansku i horacijevsku tradiciju već i na medievalni neoplatonizma, patristiku i enciklopedijsku tradiciju). Čevrto, humanizam nije „nov” pokret koji je zamijenio skolastičku kulturu (skolastika i humanizam razvijaju se usporedno; ono što je „novo” zapravo je humanističko nastojanje da se pjesništvo postavi kao fokalno mjesto novog kurikula, pritom humanističke definicije sadržaja, naravi i funkcije pjesništva slijede klasične i medievalne tradicije). Peto, skolastičke poetike - koje se zasnivaju na Aristotelu i Akvinčevu tumačenju Aristotela - niječu pjesništvu vodeću ulogu među slobodnim umijećima (Akvinac je smatrao da su slobodna umijeća, artes liberales, ljudska invencija i stoga nedostatne za utemeljenje teorijske filozofije i teologije - jedine božanske znanosti; nadalje, skolastici su smatrali da je Biblija najbolji tekst za obrazovanje mladih, a ne „poganski” autori). Šesto, postoji kontinuitet između medievalnog i ranonovovjekovnog humanističkog neoplatonizma i renesansnog platonizma (neoplatonizam ranih humanista koji su svoje ideje crpili posredno iz radova Augustina, Makrobija, Boetija, Škole iz Chartresa i dr. te kasnijih humanista poput Marsilia Ficina, koji su svoje ideje zasnivali neposredno na Platonu nije u diskrepanciji; ilustrativan primjer kontinuiteta ranohumanističkog neoplatonizma i kasnijeg platonizma Salutatijev je De laboribus Herculis) (Greenfield 1981: 308-316).

43 Polemika Mussato - Giovannino iz Matove bila je minorna epizoda ograničena na ranu četrnaestostoljetnu padovansku elitu, dok je polemika Salutati - Dominici imala korijene u širem kulturnom kontekstu (Woodward 1963: 120). 
za humaniste je Herkul postao mitski egzemplum moralnog života (primjerice: Landino, Bruni, Vergerio) (Ibid.: 144-145). Ne čudi stoga da je Marulić u središte razgovora Pjesnika ${ }^{44}$ i Bogoslova stavio upravo Herkula. Iz razgovora jasno proizlazi - što je ustvrdio Lučin - da je Maruliću „zazoran tipološki odnos" između Krista i Herkula. Međutim, iako iz razgovora nije tako jasno da je Maruliću zazorna i tropološka alegoreza (štoviše, čini se da je upravo suprotno) kojom bi se iz mitologije izvodila svojevrsna philosophia moralis (koja bi trebala biti ljudski vodič pri iznalaženju načina „kako urediti vladanje u životu"), ${ }^{45}$ mislim da se iz njegova opusa, a u nekoj mjeri i iz sâmog Dijaloga može naslutiti da Marulić zastupa „otajstvenu tropologiju” redovničke egzegetske tradicije i odbacuje humanističke tendencije ekstendiranja alegorije/alegoreze na „pjesničke bajke i izmišljotine”, odnosno tropološku moralizaciju mitova. Uvjerenjem da Biblija, a ne „pjesničke pričice” treba biti ljudski vodič pri iznalaženju načina „kako urediti vladanje u životu”, Marulić se postavio u liniju autora poput Giovannija Dominica, Savonarole i Bernardina iz Siene, a ne među predstavnike „teološke poetike”.

Završit ću riječima de Lubaca, koje, smatram, smjerodavno upućuju na Marulićevu misao: „Kako može dobar um pobrkati 'alegorijsku' interpretaciju, primjerice, [...] povijesti Davida [...], kako ju je predlagala kršćanska tradicija, s pitagorejskom 'egzegezom' koja je, primjerice, u Herkulu vidjela snagu prirode [...]” i: „,Je li se ikoji kršćanin ikada poduhvatio opravdavanja Biblije ili Evanđelja tvrdeći, kao Teon Aleksandrijski i drugi o svetim grčkim tekstovima, da je u njima nužno vidjeti 'lažljivi diskurs koji izražava istinu slikama'?" (de Lubac 2000: 17-18) Da rasprava koju su vodili Bogoslov i Pjesnik (skolastici i humanisti) nipošto nije završena, između ostalih, pokazuju - da navedem jednog teologa i jednog književnog teoretičara Hans W. Frei i Northrop Frye. Prvi je prvo svojom utjecajnom knjigom The Eclipse of Biblical Narrative (Yale University Press, 1974) ukazao na promjene tumačenja „doslovnog značenja” od pojave reformacije pa sve do dvadesetog stoljeća, a potom je i sâm razvio inovativan koncept sensus

44 B. Lučin je primijetio da je Pjesnik „istinski predstavnik humanizma”: poznaje antičku mitologiju i drži je obvezujućom u moralnom i pjesničkom smislu; poziva se na Diodora Sicilskog s tipičnim štovanjem auctores; u svojim izlaganjima služi se citiranjem Vergilija; drži do slave (laus, gloria) i glasa (Fama), njegova definicija epskog pjesništva („[...] me magis delectat ducum regumque facta suscipere”) nalik je Horacijevoj („Res gestae regumque ducumque et tristia bella quo scribi possent numero, monstravit Homerus" (Lučin 1993: 34).

45 O Marulićevoj „filozofiji morala” up. Balić 2016. 
litteralis (čitanje evanđelja kao „realističke naracije” koja donosi askripcijsku deskripciju Isusa iz Nazareta u njegovoj identitetskoj jedinstvenosti, a ne kao svojevrsni „religijski simbol”) (Frei 1993: 117-153). Drugi je istaknuo da je jedno od središnjih mjesta njegove knjige The Great Code „priroda literalnog značenja" (Frye 1982: 45) - što je objasnio komentirajući Danteovo tumačenje sheme četverostrukog smisla (Il Convivio 2. 1, 2-9). Frye, naime, ističe da za Dantea polisemija ne podrazumijeva različita značenja, već jedinstven proces rasta poput onoga kada se iz sjemena razvija biljka (Frye 1982: 221; usp. Frye 1957: 77).

\section{Literatura}

Auerbach, Erich (1984) Scenes from the Drama of European Literature, University of Minnesota Press, Minneapolis.

Badalić, Josip (1967) „Marulićevi hrvatski autografi u Arhivu Jugoslavenske akademije", Filologija, 1, 37-57.

Balić, Davor (2016) Etički nauk Marka Marulića, HAZU, Zavod za znanstvenoistraživački i umejtnički rad Koprivničko-križevačke županije, Zagreb - Križevci.

Baumann, Winfried (1984) Die 'Davidias' des Marko Marulić, Verlag Peter Lang, Franfurt am Main - Berlin - New York.

Béné, Charles (1994) „Herkul, figura Krista u hrvatskoj renesansnoj književnosti”, prevela Vera Miloš, Colloquia Maruliana, 3, 150-155.

Béné, Charles (2001) „Marulić et Erasme, lecteurs de saint Jérôme”, Colloquia Maruliana, 10, 29-45.

Bojović, Zlata (1989) „Marulićeve posvete”, Dani Hvarskoga kazališta, 15, 34-46.

Brown, Raymond E. (1968) „Hermeneutics”, The Jerome Biblical Commentary, ur. Raymond E. Brown, Joseph A. Fitzmyer i Roland E. Murphy, Prentice - Hall, Inc New Jersey, 605-623.

Camporeale, Salvatore I. (2001) „Poggio Bracciolini versus Lorenzo Valla: The Orationes in Laurentium Vallam", Perspectives on Early Modern and Modern Intellectual History. Essays in Honor of Nancy S. Struever, ur. Joseph Marino i Melinda W. Schlitt, University of Rochester Press, New York, 27-49.

Curtius, Ernst Robert (1948) Europäische Literatur und lateinisches Mittelalter, A. Francke AG Verlag, Bern. 
de Lubac, Henri (1998) Meideval Exegesis I, preveo Mark Sebanc, William B. Eerdmans Publishing Company - T\&T Clark.

de Lubac, Henri (2000) Meideval Exegesis II, preveo Edward Macierowski. William B. Eerdmans Publishing Company - T\&T Clark.

Dominici, Giovanni (1940) Lucula noctis, ur. Edmund Hunt, Notre Dame, Indianapolis.

Eco, Umberto (2001) Estetički problem u Tome Akvinskoga. preveli Sanja Roić i Augustin Pavlović, Nakladni zavod Globus, Zagreb.

Fališevac, Dunja (1991) „De raptu Cerberi J. Bunića i Dialogus de laudibus Herculis M. Marulića", Dani Hvarskog kazališta, 17, 67-80.

Fancev, Franjo (1933) „Nova poezija Splićanina Marka Marulića”, Rad JAZU, 245, 1-73.

Frei, Hans W. (1993) Theology \& Narrative, prir. George Hunsinger i William C. Placher, Oxford University Press, New York - Oxford.

Frye, Northrop (1957) Anatomy of Criticism, Princeton University Press, New Jersey.

Frye, Northrop (1982) The Great Code, Routledge and Kegan Paul, London Glavičić, Branimir (1981) „O još jednom Marulićevu novootkrivenom tekstu”, Forum, 20, 3, 329-337

Glavičić, Branimir (1989) „O Marulićevu alegorijskom tumačenju Davidijade”, Dani Hvarskog kazališta, 15, 152-161.

Glavičić, Branimir (1992) „Marko Marulić i Erazmo Roterdamski”, Latinska manja djela I. preveo, komentirao, priredio latinski tekst i dodao kazala Branimir Glavičić, Književni krug Split, Split, 9-16.

Greenfield, Concetta Carestia (1981) Humanist and Scholastic Poetics (12501500), Associated University Press, London - Toronto.

Grmača, Dolores (2015), Nevolje s tijelom, Matica hrvatka, Zagreb.

Jovanović, Neven (2004) „Tipografske i tekstološke posebnosti Marulićeva Dijaloga o Herkulu", Colloquia Maruliana, 13, 67-88.

Kapetanović, Amir (2011) „Versificirana biblijska pripovijest o Esteri (XVI. st.) u kontekstu hrvatske srednjovjekovne književne baštine i Marulićeva pjesničkog kruga", Colloquia Maruliana, 20, 5-30.

Kraljić, Ivan C (2017) „Le Dialogus de Hercule de Marko Marulić et sa dédicace érasmophile: peut-on dire, et dans quel sens, que Marulić était érasmien?" Colloquia Maruliana, 26, 239-260. 
Kristeller, Paul Oskar (1961) Renaissance Thought: The Classical, Scholastic and Humanist Strains, Harper \& Row, New York - Evanston - London.

Lučin, Bratislav (1993) „Marulićev Hercules Moralisatus (o alegoriji u Dijalogu o Herkulu)", Colloquia Maruliana, 2, 16-35.

Lučin, Bratislav (2000) „Gli studia humanitatis del Marulić”, Colloquia Maruliana, 9, 57-75.

Lučin, Bratislav (2001) „Marko Marulić i theologia rhetorica”, Colloquia Maruliana, 10, 103-111.

Lučin, Bratislav (2004) „Erazmo i Hrvati XV. i XVI. stoljeća”, Prilozi za istraživanje hrvatske filozofske baštine, 30, 1-2, 5-29.

Manavski, Venesa (2017), Dialogus de laudibus Herculis Marka Marulića: odnos teologije i književnosti, doktorski rad, Zadar.

Marsh, David (1980) The Quattrocento Dialogue, Classical Tradition and Humanist Innovation, Harvard University Press, Cambridge London.

Marulić, Marko (1984) Davidijada, preveo i komentirao Branimir Glavičić, latinski tekst priredio Veljko Gortan, Književni krug Split, Split.

Marulić, Marko (1992) Latinska manja djela I, preveo, komentirao, priredio latinski tekst i dodao kazala Branimir Glavičić, Književni krug Split, Split.

Marulić, Marko (2018) Hrvatski stihovi i proza, priredio i transkribirao Bratislav Lučin, Matica hrvatska, Zagreb.

Nemetz, Anthony (1959) „Literalness and the Sensus Litteralis”, Speculum, 34, 76-89.

Novaković, Darko (1991) „Bunićeva Otmica Kerbera - podrijetlo priče, podrijetlo alegorije”, Dani Hvarskog kazališta, 17, 81-106.

Novaković, Darko (2000) „Marulićeva Davdijada i kasnoantički kršćanski epičari”, Colloquia Maruliana, 9, 205-217.

Novaković, Darko (2005) „S onu stranu Davidijade: Marulićeve kraće latinske pjesme", Marko Marulić, Latinski stihovi, prir. i preveli Bratislav Lučin i Darko Novaković, Književni krug Split, Split, 43-80.

Palameta, Miroslav (2017) Patristička egzegeza i Marulićeva Davidijada, Književni krug Split - Filozofski fakultet u Split, Split.

Pandžić, Zvonko (2009) Nepoznata proza Marka Marulića, Tusculanae Editiones, Zagreb. 
Parlov, Mladen (1996) „Lik Krista patnika u misli Marulića”, Colloquia Maruliana, 5, 57-85.

Parlov, Mladen (1998) „Marulićeva nauka o spasenju”, Colloquia Maruliana, 7, 59-73.

Parlov, Mladen (1999) „Opuscula theologica sv. Tome Akvinskoga u misli Marka Marulića”, Colloquia Maruliana, 8, 97-108.

Posavec, Zlatko (1989) „Marulićev Dialogus de laudibus Herculis”, Dani Hvarskog kazališta, 15, 253-267

Posset, Franz (2013) Marcus Marulus and the Biblia Latina of 1489., Böhlau, Verlag Köln - Weimar - Wien.

Preus, James Samuel (1696) From Shadow to Promise: Old Testament Interpretation from Augustine to the Young Luther, Belknap Press of Harvard University Press, Cambridge.

Pšihistal, Ružica (2002) „Treba li Marulićeva Judita alegorijsko tumačenje?” Colloquia Maruliana 11, 153-184.

Pšihistal, Ružica (2004) „Davidijada u alegorijskom ključu”, Republika 60, 3, 51-55.

Pšihistal, Ružica (2005), Struktura i funkcija alegorije u Marulićevim epskim djelima: Juditi, Davidijadi i Suzani, doktorski rad, Zagreb.

Roberts, Michael (1985) Biblical Epic and Rhetorical Paraphrase in Late Antiquity, Francis Cairns, Liverpool.

Springer, Carl. O. A. (1988) The Gospel as Epic in Late Antiquity: the Paschale carmen of Sedulius, Brill, Leiden.

Šanjek, Franjo (1989) „Marko Marulić i duhovna gibanja u doba restauracije (16/17. stoljeće)", Dani Hvarskoga kazališta, 15, 63-73.

Tomasović, Mirko (1986) „Marulićev dijalog o mitologiji i literaturi”, Umjetnost riječi, 30, 1, 89-97.

Tomasović, Mirko (1996) Sedam godina s Marulom, Književni krug Split Marulianum, Split.

Trinkaus, Charles (1970) In Our Image and Likeness. Humanity and Divinity in Italian Humanist Thought I-II, Constable, London.

Ullmann, Berthold Louis (1963) The Humanism of Coluccio Salutati, Editrice Atenore, Padova.

von Erdamnn-Pandžić, Elisabeth (2000) „Zur Poetik von Marko Marulić”, Colloquia Maruliana, 9, 315 - 326. 
von Erdamnn, Elisabeth (2010) „Marko Marulić zwischen Poetik und Theologie", Colloquia Maruliana, 19, 125-139.

Woodward, William. H. (1963) Vittorino da Feltre and Other Humanist Educators, Bureau of Publications - Theachers College - Columbia University, New York.

Zlatar, Andrea (1991) Marulićeva Davidijada: Epska tehnika i biblijski predložak u Marulićevu spjevu 'Davidias', Latina et Graeca, Zagreb.

SUMMARY

Krešimir Šimić

ONCE AGAIN ABOUT ALLEGORY IN MARULIĆ'S DIALOGUS DE HERCULE

The paper opens with an introduction to the previous research on Marulićs Dialogus de Hercule a Christicolis superato, where more attention is given to Bratislav Lučin's work Marulicev Hercules Moralisatus (o alegoriji u Dijalogu o Herkulu). Then we focus on the patristic-medieval tradition of interpreting allegory and tropology. Finally, we conclude that in the Dialogus Marulić rejects not only the humanistic tendencies of extensions of allegory to mythology, but also the humanistic tropological interpretation of mythology.

Key words: Marko Marulić; Dialogus de Hercule a Christicolis superato; allegory/allegoresis; patristics; scholasticism; humanism 